\title{
Urban Infrastructure Development and Financial Allocation for the Various Urban Development Programmes and Schemes in Haryana
}

\author{
Ranjit Singh
}

\begin{abstract}
Urban local bodies across the country have been facing the problem of rapidly increase urban population. It is the duty of the state government to provide good civic amenities to the citizen, in congruence increasing needs of the enhanced urban population. This article deal with state government efforts to provide services to its citizen to fulfill this goal, the state government had initiated large number of programme and schemes. These programme or schemes are either central sponsored, in central state partnership or fully state sponsored.
\end{abstract}

The state of Haryana was created $1^{\text {st }}$ November 1966 by divided by the erstwhile state of Punjab. Since then many step have been taken so for by the state government to enhance urbanization. The process of urbanization in the state caught momentum during the last three decades. Consequently the decennial population growth rate in urban population of the state has multiplied more then twice, $43.4 \%$ and $50.8 \%$ as compared to the rural, i.e. 22.92 and 21.12\% during 1981-1991 and 1991-2001 respectively. Presently, there are 76 Urban Local Bodies in the State of Haryana consisting of 9 Municipal Corporations, 14 Municipal Councils, and 53 Municipal Committees. Government is providing financial assistance to municipalities under various programmes and schemes Jawaharlal Nehru National Urban Renewal Mission (JNNURM), Urban Infrastructure Development Scheme for Small \& Medium Towns (UIDSSMT), Integrated Housing \& Slum Development Program (IHSDP), Urban Solid Waste Management \& Rajiv Gandhi Urban Development Mission.

\section{Urban Infrastructure Development Scheme For Small \& Medium Towns (UIDSSMT)}

Urban Infrastructure Development Scheme for Small \& Medium Towns (UIDSSMT) was launched in December 2005, which aims at improvement in urban infrastructure in towns and cities (other than JNNURM cities) in a planned manner. The scheme has subsumed the existing schemes of Integrated Development of small and Medium Towns (IDSMT) and seeks to enhance public and private investments in infrastructure development in urban areas. Haryana Urban Infrastructure Development Board is the nodal agency for the scheme. Haryana government were submitted 8 Detail Project Reports costing Rs. 264.71 crore to Government of India against which Government of India has approved projects costing Rs.164.07 crore with central share of Rs. 131.26 crores for Projects of Rohtak, Karnal - Indri, Yamuna Nagar - Jagadhari, Bahadurgarh, Ambala Sadar, Narnaul and Charkhi Dadri have been approved by GOI. Provision for Rs 103.58 crore has been made in 2012-13 state budget out of which 18.64 crore has been already released.

\section{Integrated Housing \& Slum Development Programme (Ihsdp)}

The scheme of IHSDP was launched by Government of India (GOI) in December, 2005 by replacing the schemes namely, National Slum Development Programme (NSDP) and Valmiki Ambedkar Awas Yojana (VAMBAY). In Haryana under this scheme, 18 projects for 15 towns costing Rs. 262.13crore have been approved by GOI, out of which GOI share is Rs. 209.71 crore. An amount of Rs. 104.85 crore was released by GOI as central share and Rs. 26.22 crore was released by state government of state share. The GOI had earmarked an amount of Rs. 133.05 crore for IHSDP for Mission period 2005- 12 against which DPRs (Detail Project Report) having Central Share of Rs. 209.71 crore has already been approved. Under this program 7537 housing units has been constructed and work of 2165 units is in progress. For this program Rs. 179.76 carore has been distributed to council in budget year 2012-1013.

\section{Integrated Low Cost Sanitation Scheme (Ilcs)}

This scheme was launched by Government of India (GOI) in 2008 with an objective to convert / construct low cost sanitation units. Under this construct new latrines where economically weaker section (EWS) household have no latrine. Cost of each unit is Rs. 10,000, Out of this, $75 \%$ of the cost shall be borne by GOI as grant, $15 \%$ by the State and $10 \%$ by the beneficiary. All towns are covered and are to taken-up on whole town basis / whole colony basis. Due to limited funds available, priority is to be given to towns having predominantly dry latrines. The government of Haryana was submitted 6 detail project report (for Rohtak, Ambala-City, 
Ambala-Sadar, Kaithal, Faridabad and Panchkula) to Ministry of Housing and Urban Poverty Alleviation, Government of India. The Secretary to GOI, Ministry of Housing and Urban Poverty Alleviation, has pointed out that due to constraint of funds, only one town may be considered as per priority of the state government. In addition, it has also been pointed out that total sanitation approach must be followed. The government of Haryana has submitted revised detail project report for total sanitation of Ambala. The same have been submitted to HUDCO (Housing and Urban Development Corporation) for onward submission to Ministry of Housing and Urban Poverty Alleviation for approval. During the year 2011-12, a budget provision of Rs.2.00 crore has been approved with the provision of Rs. 1.68 crore as Additional Central Assistance (ACA) \& Rs.0.32 crore as State Share. During current fiscal year 2012-2013 there is provision for Rs.1.00 crore.

\section{Urban Solid Waste Management}

The municipalities are monitoring sanitation in the towns but the solid waste management system as a whole needs improvement. A High Powered Committee was constituted by the Planning Commission; it has submitted its recommendations regarding Solid Waste Management. Government of India has earmarked an allocation of Rs. 91.00 crore against the recommendations of Central Finance Commission for the years 2005-10 for the State of Haryana. Out of which, 50\% of the funds are to be utilized for Solid Waste Management (SWM) and balance $50 \%$ on development works, as per the guidelines of the Central Finance Commission. Rs. 36.40 crore received during 2005-09 have been released to municipalities for procurement of land for SWM( Solid Waste Management) plants and vehicles and equipments for transportation of SWM. Four Detailed Project Reports (DPRs) costing Rs. 131.70 crore for Solid Waste Management of Faridabad, Rohtak, Karnal - Indri \& Yamunanagar- Jagadhari have been approved by Ministry of Urban Development, Government of India under JNNURM \&UIDSSMT. A provision of Rs. 6.13 crore has been made for Solid Waste Management for the year 2011-12. Rs. 313 crore has been provided for this scheme during current financial year 2012-2013.

\section{Scheme For Development Of SC Basties}

In order to provide the benefit to SC Basties other than those covered under the scheme Development of Municipal Wards with more than 50\% SC population, department has made a provision of Rs. 21.37 crore for development of these Basties. These funds shall be exclusively utilized as SCSP (Schedule Caste Sub Plan) scheme. All the municipalities have been directed to submit the project proposal of any of the following development work to be executed in these SC Basties for providing the benefit to SC population. The budget provision of Rs. 50.00 crore has been approved for the year 2010-11. During the year 2011-12, a budget provision of Rs. 50.00 crore has been approved. Rs.33.87 crore has been provided for this scheme during current financial year 2012-2013.

\section{Strengthening Of Fire Prevention Services}

The scheme was introduced during the year 2009-10 by Government of India. The scheme is centrally sponsored. Fire Prevention Services are one of the most important services in the State. A budget provision of Rs. 2.50 crore was made as state share for the year 2010-11 to compensate the central share of Rs. 10.00 crore approved by Government of India. Accordingly; a similar provision of Rs. 2.50 crore has been allocated for the approved Annual Plan 2011-12 as State Share. However, Central Share of Rs. 10.00 crore is also required to be made in the state budget.

\section{Centrally Sponsored Scheme Of Urban Infrastructure Development In Satellite Towns around Mega Cities}

In order to develop urban Infrastructure facilities such as transport, drinking water, sewerage, drainage and Solid waste management etc. at satellite towns of the 7 mega cities like Mumbai, Kolkata, Delhi, Chennai, Hyderabad, Bangalore and Ahmedabad, Government of India has approved a Centrally Sponsored Scheme of Urban Infrastructure Development in Satellite Towns around Mega cities. Hence, a budget provision of state share of Rs. 10.00 crore has been approved in the state budget. However, central share of Rs. 80.00 crorer is also required to be made in the state budget. Sonipat has been selected as satellite town under this scheme due to proximity of Delhi. To DPRs (Detail Project Report) for solid west management and water supply for Sonipat town Rs. 24.96 crore and Rs. 69.58 crore has been released respectively for solid waste management and water supply. Finance department of GOI released Rs. 18.90 crore and state government released 2.36 crore toward Sonipat municipality.

\section{Rajiv Gandhi Urban Development Mission, Haryana (Rgudmh) (Share of Surcharge on VAT) \\ The Government has launched a State-wide urban infrastructure development programme namely Rajiv Gandhi Urban Development Mission, Haryana (RGUDMH), on mission mode approach, in all the Urban Local}


Bodies of the state excluding Municipal Corporation, Gurgaon and towns those covered under Jawaharlal Nehru National Urban Renewal Mission (JNNURM) of Government of India. The objective of the Rajiv Gandhi Urban Development Mission, Haryana (RGUDMH) would be an integrated development of the city/town in a holistic manner within a time frame of five years, with focus on efficiency in urban infrastructure / services delivery mechanism, community participation and accountability of urban local bodies towards citizens. The Government proposes to earmark an allocation of Rs. 2500 crore under RGUDMH to be spent over a period of five years with a yearly breakup of Rs 500 crore. The following three components are proposed to be included in the Rajiv Gandhi Urban Development Mission:-

1. Social / Rental \& Affordable Housing Rs. 100.00 crore.

2. Water Supply, Storm Water, Drainage \& Sewerage Rs. 200.00 crore.

3. Urban Sanitation / Cleanliness / SWM /other Civic Infrastructure Rs. 200.00 crore.

During the year 2011-2012 Rs. 550.39 crore were released to the various municipality.

Under the Mission, a provision of Rs.360.00crores has been approved in the budget for the year 2012-13 out of which Rs. 273.11 crore has been released.

\section{Rajiv Gandhi Shahri Bhagidari Yojna (Rgsby)}

Government of Haryana has introduced the Rajiv Gandhi Shehri Bhagidari Yojna under Rajiv Gandhi Urban Development Mission, Haryana (RGUDMH) during the current financial year with an objective of institutionalizing citizens' participation in municipal functioning by setting up of the Area Sabha and Ward Committee in urban areas. This would ensure involvement of citizens in setting up priorities, preparing ward plans and budgets, exerting pressure on compliance of regulation, etc. RGSBY will focus on construction and management of community hall/Center, community parks, roads and back lanes on regular basis, community Toilets, cattle pounds for stray animals, street lights, infrastructure for door to door collection and transportation of solid waste/garbage, internal colony water supply and sewage system. A budget provision of Rs. 10.00 crore was made for RGSBY during the financial year 2010-11. A provision of Rs. 10.00 crore has been approved under the scheme during the year 2011-2012. During last fiscal year 2011-2012, under this scheme Rs. 1.70 crore were released for Hisar and Panipat municipality. During current fiscal year 2012-2013 provision for Rs. 2.68 crore.

\section{Rajiv Awas Yojana}

The Ministry of Housing \& Urban Poverty Alleviation, Government of India has launched a scheme of Rajiv Awas Yojana (RAY) for assisting the states to make cities slum free. The Ministry has issued detailed guidelines for Slum Free City Planning under RAY. As per these guidelines, the State is required to prepare Slum Free City Plans. The Slum free City Plan will broadly involve Slum Redevelopment/Rehabilitation Plans based on (a) survey of all slums-notified and non-notified; (b) mapping of slums using the state of art technology; (c) integration of geo-spatial and socio-economic data; and (d) identification of development model proposed for each slum. Base maps to an appropriate scale would be a pre-requisite for the preparation of Slum Redevelopment Plan/Slum-free City Plan. The Government of India has sanctioned Rs. 168.636 crore for the state for Slum Free City Planning under RAY. During fiscal year 2011-2012 Rs. 65.35 crore were provided which also included Rs 10 crore by state government and for the current fiscal year 2012-2013 there is a proposal for Rs. 19.00 crore.

\section{Training Of Women Councilors Of Urban Local Bodies In Haryana}

As per 74th Constitutional Amendment, 33\% reservation for the women in the office of President/Mayor and Municipal Councils in the Urban Local Bodies has been made. It has been observed that the representation of women in the decision making levels has been quite marginal which requires special intervention, to help raise their representation. A training for elected women Councilors regarding role and responsibility, power and functions was approved by the Haryana Institute of Public Administration. Accordingly, a proposal was sent to the Government of India to provide the Grant-in-aid and for the training of the elected women Councilors in the State. A budget provision of Rs.0.04crores was approved for the year 2010-11. During the year 2011-12, a similar budget provision of Rs. 0.04crores is approved for budget.

\section{Shifting Of Milk Dairies Out Of MC Limits}

State government decided to shift milk dairies outside the municipal council boundaries. For this purpose the State Environmental Protection Council decided that funds would be made available for various projects of shifting of Milk dairies out of municipal council limits. Accordingly, a token provision of Rs. 1.37 crore was made in the budget during the year 2008-09 and the same has been released to Municipal Committee, Gohana for purchase of land. After this fund amounting to Rs. 3.14 crore were provided in year 2009-10. Provision of Rs 1.25 crore has been approved every year since financial year 2010-2011. 
XIII. Jawaharlal Nehru National Urban Renewal Mission (Jnnurm)

Jawaharlal Nehru National Urban Renewal Mission (JNNURM) was launched on December 3, 2005, for integrated development of 63 identified cities of India. The funds under JNNURM are released to the states by central government in the form of Additional Central Assistance (ACA) as 100\% grant. The project period of JNNURM is 7 years (2005 to 2012) and funds under JNNURM are predicated on states agreeing to the reforms agenda.

\section{Sub Mission I - Urban Infrastructure And Governance (UIG)}

The main thrust of the Sub-Mission I on Urban Infrastructure and Governance is on major infrastructure projects relating to water supply including sanitation, sewerage, solid waste management, road network, urban transport and redevelopment of old city areas. Haryana Urban Infrastructure Development Board is the nodal agency for this Sub- Mission.

\section{XV. $\quad$ Sub-Mission II - Basic Services To Urban Poor (BSUP)}

The main thrust of the Sub-Mission II on Basic Services to the Urban Poor is on integrated development of slums through projects for providing shelter, basic services and other civic amenities to the urban poor. Haryana Slum Clearance Board is the nodal agency for this Sub-Mission. Initially, only Faridabad town of the State was covered under the scheme. Now, Panchkula town has also been included under JNNURM, along with Chandigarh and Greater Mohali. CDP for Faridabad Town costing Rs. 2679.11 crore was approved by Government of India. The Panchkula town was included under JNNURM, along with Chandigarh and Greater Mohali by GOI. State government was prepared the City Development Plan of Greater Panchkula costing of Rs. 6019.38 crore which was approved by Government of India(GOI). The GOI had earmarked an amount of Rs. 223.32 crore for Sub-Mission-I (Urban Infrastructure and Governance (UIG)) and Rs. 32.31 crore for Sub- Mission -II (Basic Services to Urban Poor (BSUP)) for the total Mission period 2005-12. During the year 2011-12, a budget provision of Rs. 174.04 crore has been approved with a provision of Rs. 139.232 crore as Additional Central Assistance (ACA) \& Rs. 34.808 crore as State Share.

ALOCATION OF GRANTAS TO VARIOUS MUNICIPALITYIN YEARS 2000-2001 TO2004-2005

\begin{tabular}{|l|l|l|l|l|}
\hline $\begin{array}{l}\text { SR } \\
\mathbf{N}\end{array}$ & FINANCIAL & $\begin{array}{l}\text { ALLOCATION OF FUNDS } \\
\text { THROUGS VARIOUS } \\
\text { SCHEMES (IN LACKS) }\end{array}$ & $\begin{array}{l}\text { ALLOCATION OF FUNDS } \\
\text { THROUGS L.A.D.T. } \\
\text { LACKS) }\end{array}$ & $\begin{array}{l}\text { TOTAL (IN } \\
\text { LACKS) }\end{array}$ \\
\hline 1 & $2000-01$ & 24.35 & - & 24.35 \\
\hline 2 & $2001-02$ & 22.84 & - & 22.84 \\
\hline 3 & $2002-03$ & 36.10 & - & 36.10 \\
\hline 4 & $2003-04$ & 36.32 & 30.00 & 66.32 \\
\hline 5 & $2004-05$ & 41.29 & 39.50 & 80.79 \\
\hline & TOTAL(2000-2005) & 160.89 & 69.50 & 230.39 \\
\hline
\end{tabular}

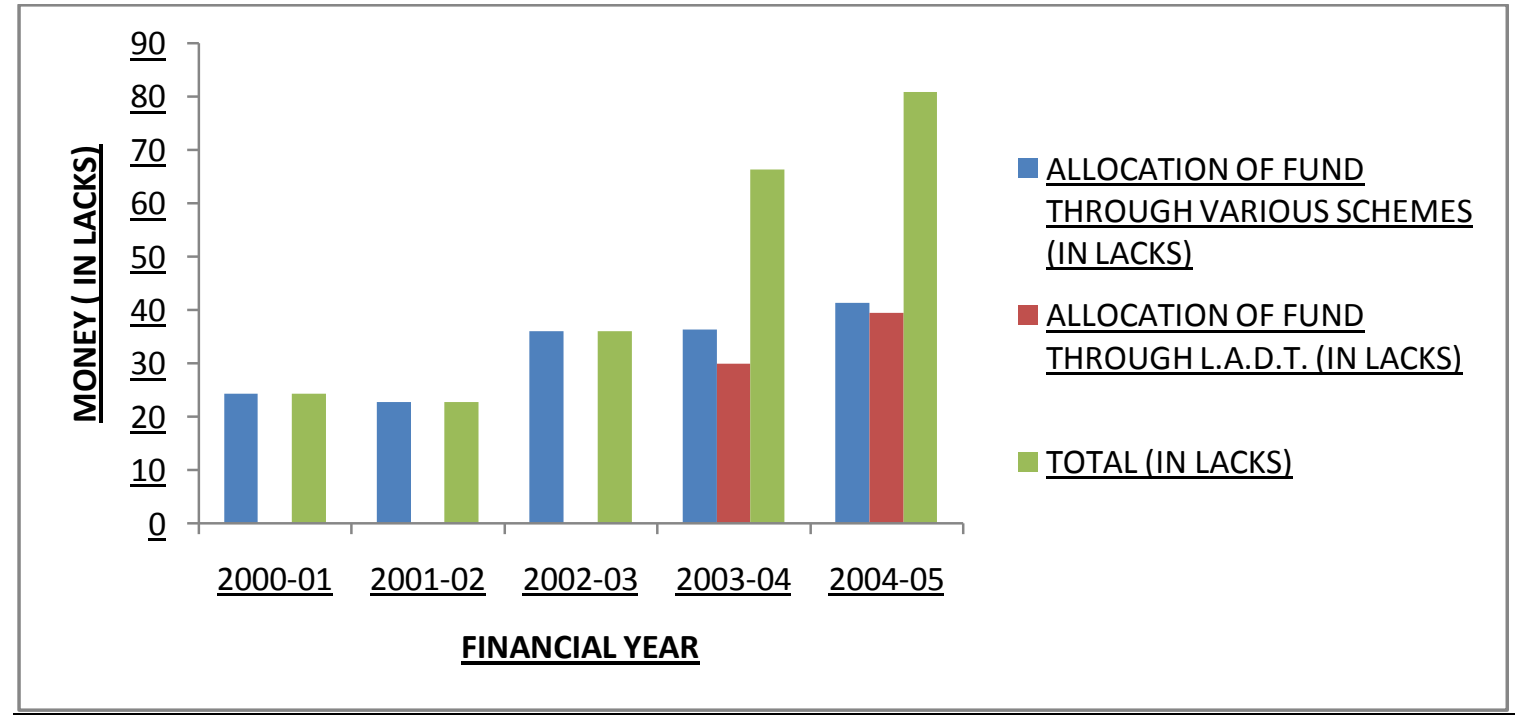

*L.A.D.T. (Local Area Development Tax) 
ALLOCATION OF GRANTS TO VARIOUS MUNICIPALITIES IN YEARS 2005-2006 TO2012-1213

\begin{tabular}{|l|l|l|l|l|l|}
\hline $\begin{array}{l}\text { SR } \\
\mathrm{N}\end{array}$ & FINANCIAL & $\begin{array}{l}\text { ALLOCATION OF } \\
\text { FUNDS THROUGS } \\
\text { VARIOUS SCHEMES } \\
\text { (IN LACKS) }\end{array}$ & $\begin{array}{l}\text { ALLOCATION OF FUNDS } \\
\text { THROUGS L.A.D.T. } \\
\text { LACKS) }\end{array}$ & $\begin{array}{l}\text { TOTAL (IN } \\
\text { LACKS) }\end{array}$ \\
\hline 1 & $2005-06$ & 94.39 & 115.80 & 210 \\
\hline 2 & $2006-07$ & 44.14 & 129.64 & 173.38 \\
\hline 3 & $2007-08$ & 62.52 & 107.27 & 169.79 \\
\hline 4 & $2008-09$ & 319.96 & 103.50 & 423.46 \\
\hline 5 & $2009-10$ & 585.47 & 19.80 & 605.27 \\
\hline 6 & $2010-11$ & 281.01 & - & 281.01 \\
\hline 7 & $2011-12$ & 893.59 & 10.34 & 903.93 \\
\hline 8 & $2012-13$ & 678.48 & - & 678.48 \\
\hline & TOTAL(2005-2013) & 2958.56 & 486.35 & 3445.91 \\
\hline
\end{tabular}

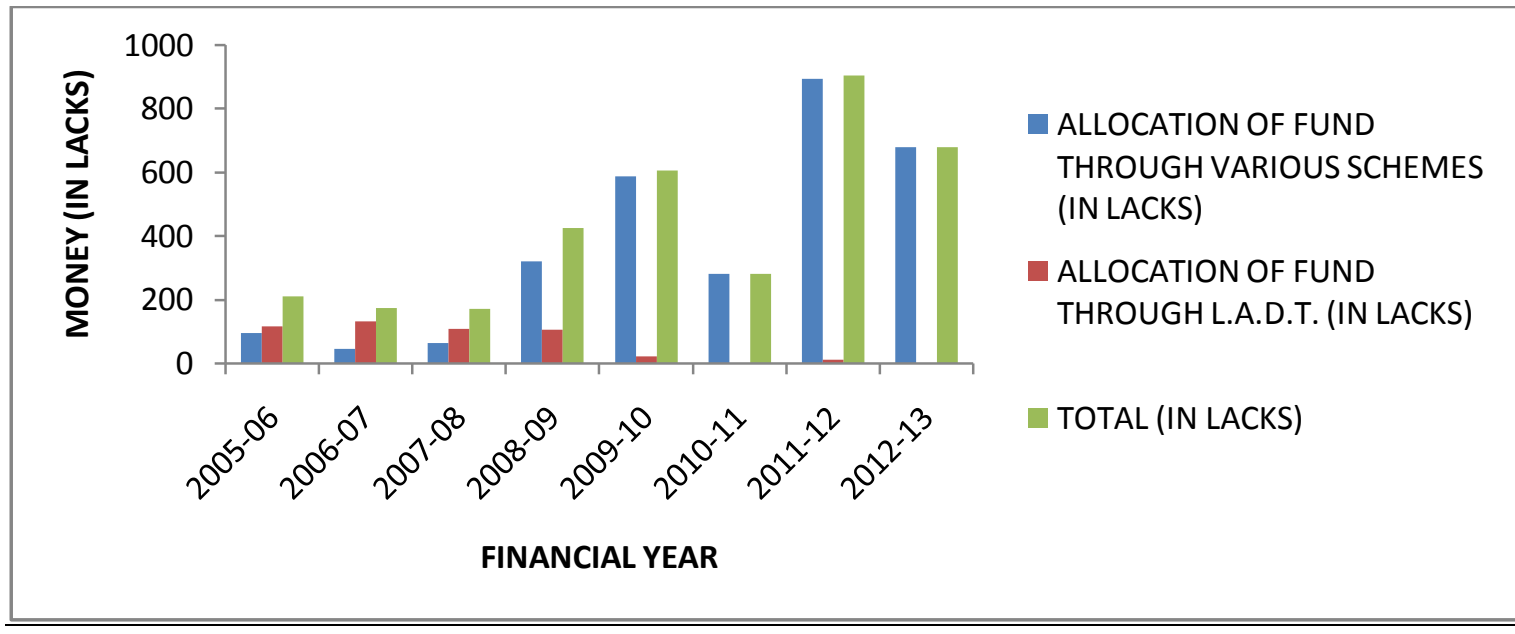

*L.A.D.T. (Local Area Development Tax)

XVI.

Conclusion

State tries to develop the urban infrastructure through many programme and schemes. It develops the mega town through JNNURM, middle town through UIDSSMT and HISDP. Problem of solid waste is being solved through USWM. For the sanitation problem integrated low costs sanitation scheme has been initiated. Development of SC Basti is been done through SCSP. Fire services are being developed and modernize to safety against any untoward accidents. To promote citizen participation in the administration ward committees have been constituted through RGSBY. To enhance the participation and to inculcate leadership quality among women, many training programme have been initiated. To tackle the problem of slums government has implemented Rajiv Awas Yojana. To provide healthy environment to its citizen, government provide funds to shift milk dairy outside the boundary of municipal council.

\section{Reference}

[1] Rajbir Singh Dalal "good governance in urban local bodies issues and challengs" nagarlok april june 2011 vol.xliii p8

[2] http://www.esaharyana.gov.in/PlanningItems/2011-12/Approved/253-527.pdf

[3] http://www.urban.bih.nic.in/Docs/IHSDP-Guidelines.pdf

[4] http://www.ulbhry.org/schemes/solidwestmanagement.pdf

[5] http://www.ulbhry.org/schemeprogress/satellitetownscheme.org

[6] http://www.ulbhry.org/schemes/shareofsurchargeonvatforulb.pdf

[7] http://ulbhry.org/Guidelines/guidelinesRGSBY.pdf

[8] http://www.esaharyana.gov.in/PlanningItems/2011-12/Approved/253-527.pdf

[9] www.urbanindia.nic.in/programme/ud/jnnurm/overview.pdf

[10] Randhir singh sangwan "urbanization in Haryana: the emerging trends" nagarlokvol.XL, april june 2008 , no 2. 